\title{
Ordem ambiental internacional e a América do Sul, seus avanços e desafios: organizações regionais e os casos nacionais da Argentina, Bolívia e Colômbia.
}

\section{Mariana Graf Mazzotti, Profa. Dra. Claudete de Castro Silva Silva Vitte}

\section{Resumo}

Esta pesquisa procurou discutir a ordem ambiental na América do Sul, com destaque para os países Argentina, Bolívia e Colômbia e como a temática vem sendo discutida nas organizações regionais Mercosul, CAN e Unasul, visando contribuir no debate acerca dos avanços e desafios na governança ambiental na América do Sul. Por meio de metodologia exploratória, houve uma revisão sobre o debate ambiental nas cúpulas da Organização das Nações Unidas, momento de legitimação internacional da temática ambiental; na sequência, as discussões de temáticas ambientais em algumas organizações sul-americanas e, por fim, como elas vêm sendo tratada nos países selecionados, observando-se avanços e desafios no trato das questões ambientais.

\section{Palavras-chave:}

América do Sul; Ordem ambiental internacional; organizações regionais sul-americanas.

\section{Introdução}

A América do Sul apresenta quase metade das florestas tropicais e um quarto de terras potencialmente produtivas do mundo. Também possui um terço das reservas de água doce do planeta, tornando o debate ambiental extremamente relevante. Contudo, o debate ambiental nas agendas dos países da região estudados nesta pesquisa é recente e ainda permanece em segundo plano, visto que ainda predomina a ênfase nas discussões sobre desenvolvimento econômico e social, sem incorporar de forma enfática a pauta ambiental

\section{Resultados e Discussão}

Foi feita uma revisão bibliográfica baseada em artigos, teses e livros, com destaque aos publicados nos últimos dez anos, tendo sido percebida uma lacuna na discussão da temática ambiental nas agendas dos países estudados. Embora esteja presente, a temática ambiental é obscurecida pelas pautas sociais e econômicas, uma vez que os países da região ainda enfrentam os desafios do desenvolvimento. Em cúpulas e reuniões internacionais os países apresentam-se sempre em blocos, com posicionamento uníssono de discurso de vinculação da temática ambiental ao desenvolvimento social. Há de se destacar, o posicionamento firme dos países sul-americanos na rejeição dos parâmetros eurocêntricos de conservação ambiental, visto que muitos deles podem acarretar prejuízos econômicos aos países da América Latina (e do Sul).

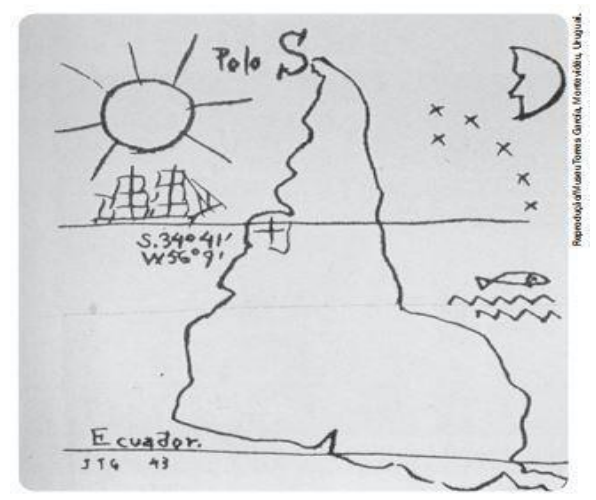

Figura 1. América Invertida. Joaquín Torres García, 1943.

\section{Conclusões}

Embora a região se destaque pelos seus recursos naturais, a América do Sul ainda enfrenta desafios na governança ambiental, ainda que se observe concordância no posicionamento dos países da região em cúpulas e encontros de temática ambiental, o subcontinente carece de uma legislação específica, maior integração e foco nas agendas ambientais dos países.

\section{Agradecimentos}

Ao PIBIC/CNPq pela oportunidade e pela bolsa concedida.

ABRAMOVAY, Ricardo. Muito além da economia verde. São Paulo: Abril 2012 .

DO LAGO, André Aranha Corrêa. Estocolmo, Rio, Joanesburgo: o Brasil e as três conferências ambientais das Nações Unidas. Thesaurus Editora, 2007.

RIBEIRO, Wagner Costa. A ordem ambiental internacional. São Paulo: Contexto, 2001.

RIBEIRO, Wagner Costa. Geografia política e gestão internacional dos recursos naturais. Estudos Avançados, v.24, n. 68. p. 69-80, 2010.

RIBEIRO, Wagner Costa. Mudanças climáticas, realismo e multilateralismo. Terra Livre, v. 1, n. 18, 2015 . 